Serambi Saintia

\title{
Kepatuhan Perawat dalam Mencuci Tangan di RSUD Datu Beru Takengon
}

\author{
Sanjaya Alamsyah ${ }^{1}$ \\ Muhammad Badiran ${ }^{2}$ \\ Masnelly Lubis ${ }^{3}$ \\ ${ }^{1,2,3)}$ Magister KesehatanMasyarakat, InstitutKesehatan Helvetia Medan \\ Kelompok Penelitian, Institut Kesehatan Helvetia Medan \\ alamsyahsanjaya @gmail.com/081262975409
}

\begin{abstract}
ABSTRAK
Infeksi nosokomial merupakan masalah di rumah sakit diseluruh dunia. Salah satu upaya pencegahan infeksi di rumah sakit, perawat melakukan tindakan cuci tangan sebelum dan sesudah tindakan keperawatan. Penelitian menggunakan metode survey analitik dengan menggunakan rancangan cross sectional. Penulisan dilakukan di Rumah Sakit Umum Datu Beru Takengon Tahun 2016/2017. Populasi dalam penulisan ini adalah seluruh perawat di ruang rawat inap sebanyak 97 orang. Sampel ditetapkan sebanyak 97 orang perawat. Pengambilan sampel secara total population. Data dikumpulkan melalui kuesioner. Data dianalisis secara univariat, bivariat dan multivariat dengan menggunakan uji Chi-Square pada taraf kepercayaan $95 \%(\mathrm{P}<0,05)$ dan regresi logistic berganda. Hasil penelitian menunjukkan ada pengaruh pengetahuan dengan nilai $p$-value 0.001 , sikap dengan nilai $p$-value 0.000 ), fasilitas dengan nilai p-value 0.025 , dan Peran Tim PPI dengan nilai p-value 0.011secarasignifikan terhadap Kepatuhan Perawat Dalam Mencuci Tangan. Hasil analisis uji regresi logistik berganda menunjukkan bahwa variabel yang paling dominan mempengaruhi kepatuhan perawat dalam mencuci tangan adalah variabel sikap yaitu pada nilai odds rasio $\operatorname{Exp}(B)$ 16.875. Berdasarkan hasil pengolahan dapat disimpulkan bahwa faktor pengetahuan, sikap, fasilitas, dan peran tim PPI memberikan pengaruh terhadap kepatuhan perawat dalam mencuci tangan, dan variabel yang paling dominan mempengaruhi kepatuhan perawat dalam mencuci tangan adalah variabel sikap.
\end{abstract}

\section{Kata kunci : Kepatuhan, Perawat, Mencuci tangan}

\section{PENDAHULUAN}

Rumah sakit adalah institusi pelayanan kesehatan yang menyelenggarakan pelayanan kesehatan perorangan secara paripurna yang menyediakan pelayanan rawat inap, rawat jalan dan gawat darurat. Gawat darurat adalah keadaan klinis pasien yang membutuhkan tindakan medis segera guna penyelamatan nyawa dan pencegahan kecacatan lebih lanjut. Pasien adalah setiap orang yang melakukan konsultasi masalah kesehatannya untuk memperoleh pelayanan kesehatan yang diperlukan baik secara langsung maupun tidak langsung di Rumah sakit (Anonimous, 2009). 
Sanjaya Alamsyah, Muhammad Badiran, dan Masnelly Lubis

Perawat adalah tenaga kesehatan profesional yang perannya tidak dapat dikesampingkan dan menjadi garda terdepan pelayanan Rumah sakit, karena tugasnya mengharuskan perawat kontak paling lama dengan pasien. Kehandalan dan keterampilan perawat merupakan prioritas kedua konsumen dalam memilih rumah sakit, disamping alasan keberadaan dokter, spesialis, karena perawat merupakan karyawan rumah sakit yang kontak paling lama dengan pasien bahkan 24 jam penuh, maka diasumsikan ikut mengambil peran yang cukup besar dalam memberikan kontribusi kejadian infeksi (Badi et. al., 2007).

Infeksi nosokomial merupakan masalah di rumah sakit diseluruh dunia 1,7 juta pertahun, dan hampir 100.000 kematian diakibatkan oleh infeksi nosokomial di Amerika. Revalensi infeksi nosokomial terjadi di Indonesia sebesar 7,1\%, infeksi nosokomial terjadi pada pasien $10 \%$, petugas $5 \%$, peralatan $30 \%$, lingkungan $10 \%$ (Sumiarty, 2016).

Salah satu infeksi nosokomial yang terjadi di Rumah Sakit adalah Phlebitis. Phlebitis merupakan infeksi nosokomial yaitu infeksi oleh mikroorganisme yang dialami oleh pasien yang diperoleh selama dirawat di rumah sakit diikuti dengan manifestasi klinis yang muncul sekurang-kurangnya 3x24 jam, dan kejadian phlebitis menjadi indikator mutu pelayanan minimal rumah sakit dengan standar kejadian $\leq 1,5 \%$ (Darmadi, 2008).

Phlebitis didefinisikan sebagai peradangan pada dinding pembuluh darah balik atau vena (Darmadi, 2008). Sejak tahun 2001 Departemen Kesehatan RI telah memasukkan pengendalian infeksi nosokomial menjadi salah satu tolak ukur dalam akreditasi rumah sakit, didalam indikator mutu layanan rumah sakit salah satunya adalah tingkat kejadian phlebitis yang dapat memberikan gambaran secara umum tentang baik maupun kurangnya mutu layanan rumah sakit tersebut (Depkes, R.I., 2008).

Salah satu upaya pencegahan infeksi di rumah sakit, perawat melakukan tindakan cuci tangan sebelum dan sesudah tindakan keperawatan. Cuci tangan merupakan salah satu penerapan perawat dalam pencegahan infeksi nosokomial, dimana kebersihan tangan adalah suatu prosedur tindakan membersihkan tangan dengan menggunakan sabun atau antiseptik dibawah air mengalir atau dengan menggunakan hand scrub yang bertujuan untuk menghilangkan kotoran dari kulit secara mekanis dan mengurangi jumlah mikroorganisme sementara (Perdalin, 2010).

Rumah Sakit Umum Daerah Datu Beru Takengon saat ini sedang menggalakkan perilaku cuci tangan pada tenaga kesehatan khususnya perawat sebagai upaya untuk mencegah terjadinya infeksi nosokomial karena tenaga kesehatan khususnya perawat adalah salah satu tenaga di rumah sakit yang secara langsung berinteraksi dengan klien dan menjadi sumber penyebab terjadinya infeksi nosokomial. Fasilitas beserta poster tentang langkah-langkah melakukan cuci tangan secara baik dan benar pada rumah sakit ini juga sudah tersedia pada tiap ruangannya, namun demikian berdasarkan hasil survei pendahuluan diketahui bahwa masih terdapat sikap perawat yang enggan untuk melakukan cuci tangan dengan berbagai alasan diantaranya perawat mengaku keterbatasan waktu yang digunakan untuk melakukan cuci tangan, kondisi pasien. Kondisi seperti ini tentu saja berdampak munculnya masalah seperti terjadinya kasuskasus infeksi.

Berdasarkan studi pendahuluan yang dilakukan oleh peneliti pada tanggal 31 September 2016 di Rumah Sakit Umum Daerah Datu Beru Takengon didapatkan data 
triwulan I s/d tribulan III bahwa terdapat kejadian infeksi nosokomial (HAIs) Phlebitis 6,83\% pada tribulan I, 5,58\% triwulan II, dan 3,03\% triwulan III (Data PPI RSUD Datu Beru Takengon). Berada diatas angka standar minimum $\leq 1,5 \%$ ((Depkes, R.I., 2008).

Berdasarkan hasil wawancara dengan Tim Pencegahan dan Pengendalian Infeksi (PPI) RSUD Datu Beru Takengon, mereka mengatakan kelalaian ini di karenakan petugas kurang menjalani prosedur cuci tangan sehingga dengan demikian kejadian infeksi masih terjadi. Berdasarkan hal tersebut, maka perlu dilakukan penelitian tentang Faktor-Faktor yang Mempengaruhi Kepatuhan Perawat Dalam Mencuci Tangan Di RSUD Datu Beru Takengon.

\section{METODE PENELITIAN}

Penelitian ini merupakan survei analitik dengan desain cross sectional yang bertujuan untuk mengetahui pengaruh faktro-faktor kepatuhan perawat dalam mencuci tangan di RSUD Datu Beru Takengon. Dimana data yang menyangkut variabel independen dan variabel dependen akan dikumpulkan dalam waktu yang bersamaan.

Penelitian ini dilaksanakan di RSUD Datu Beru Takengon.Waktu penelitian dilakukan mulai dari peneliti melakukan survei pendahuluan pada tanggal 31 September 2016, dilanjutkan dengan pengambilan data ke lapangan sampai dengan selesai pada bulan Februari 2017

Populasi dalam penelitian ini adalah seluruh perawat di ruang rawat Inap sebanyak 97 orang. Pengambilan sampel dalam penelitian ini dengan mengunakan total polulation. Total populasi ialah teknik pengambilan sampel secara keseluruhan yaitu sebanyak 97 perawat.

\section{HASIL PENELITIAN DAN PEMBAHASAN Hasil Penelitian}

Hasil distribusi variabel pengetahuan menunjukkan bahwa dari 97 perawat mayoritas berpengetahuan baik sebanyak $51(52,6 \%)$ dan minoritas buruk sebanyak 46 $(47,4 \%)$. Variabel sikap mayoritas bersikap buruk $52(53,6 \%)$ dan minoritas menyatakan sikap baik sebanyak 45 (46,4\%). Variabel fasilitas mayoritas menggunakan fasilitas dalam kategori baik sebanyak 61 62,9\%) dan minoritas buruk sebanyak 36 (37,1\%).Variabel peran Tim PPI mayoritas peran Tim PPI dalam kategori buruk sebanyak buruk $54(55,7 \%)$ dan minoritas baik sebanyak $43(44,3 \%)$. Pada variabel kepatuhan mencuci tangan mayoritas tidak patuh $49(50,5 \%)$ dan minoritas patuh $48(49,5 \%)$.

\section{Pembahasan}

Pengaruh Pengetahuan Dengan Kepatuhan Perawat Dalam Mencuci Tangan Di Rumah Sakit Umum Daerah Datu Beru Takengon

Dari 51 responden yang berpengetahuan baik sebanyak $34(35,1 \%)$ responden yang patuh dalam mencuci tangan. Sedangkan dari 46 responden yang berpengetahuan buruk ternyata sebanyak $32(33,0 \%)$ responden yang tidak patuh dalam mencuci tangan. Hasil uji statistik diperoleh nilai probabilitas $\mathrm{P}$-value $(0,001)<(0,05)$, ini berarti Ha diterima, yang berarti ada pengaruh antara pengetahuan dengan kepatuhan perawat dalam mencuci tangan di Rumah Sakit Umum datu Beru Takengon. 
Sanjaya Alamsyah, Muhammad Badiran, dan Masnelly Lubis

\section{Pengaruh Sikap Dengan Kepatuhan Perawat Dalam Mencuci Tangan Di Rumah Sakit Umum Daerah Datu Beru Takengon}

Dari 45 responden yang bersikap baik sebanyak $35(36,1 \%)$ responden yang patuh dalam mencuci tangan. Sedangkan dari 52 responden yang bersikap buruk ternyata sebanyak $39(40,2 \%)$ responden yang tidak patuh dalam mencuci tangan. Hasil uji statistik diperoleh nilai probabilitas $\mathrm{P}$-value $(0,000)<(0,05)$, ini berarti Ha diterima, yang berarti ada pengaruh antara sikap dengan kepatuhan perawat dalam mencuci tangan di Rumah Sakit Umum datu Beru Takengon.

\section{Pengaruh Fasilitas Dengan Kepatuhan Perawat Dalam Mencuci Tangan Di Rumah Sakit Umum Daerah Datu Beru Takengon}

Dari 61 responden yang menggunakan fasilitas dengan baik sebanyak 36 $(37,1 \%)$ responden yang patuh dalam mencuci tangan. Sedangkan dari 36 responden yang menggunakan fasilitas dengan buruk ternyata sebanyak $24(24,7 \%)$ responden yang tidak patuh dalam mencuci tangan. Hasil uji statistik diperoleh nilai probabilitas P-value $(0,025)<(0,05)$, ini berarti Ha diterima, yang berarti ada pengaruh antara Fasilitas dengan kepatuhan perawat dalam mencuci tangan di Rumah Sakit Umum datu Beru Takengon.

\section{Pengaruh Peran Tim PPI Dengan Kepatuhan Perawat Dalam Mencuci Tangan Di Rumah Sakit Umum Daerah Datu Beru Takengon}

Dari 48 responden yang mengatakan Peran Tim PPI baik hanya sebanyak 28 $(28,8 \%)$ responden yang patuh dalam mencuci tangan. Sedangkan dari 49 responden yang mengatakan Peran Tim PPI buruk ternyata sebanyak $34(35,1 \%)$ responden yang tidak patuh dalam mencuci tangan. Hasil uji statistik diperoleh nilai probabilitas $\mathrm{P}$ value $(0,011)<(0,05)$, ini berarti Ha diterima, yang berarti ada pengaruh antara Peran Tim PPI dengan kepatuhan perawat dalam mencuci tangan di Rumah Sakit Umum datu Beru Takengon. Hal ini membuktikan bahwa tingkat pengetahuan mempunyai pengaruh yang positif terhadap cara hidup yang sehat yaitu dengan mencuci tangan sebelum menangani pasien (Hasnadi, dkk. 2014).

\section{Hasil Analisis Multivariat Uji Regresi Logistik Berganda.}

Berdasarkan hasil uji regresi logistik berganda menunjukkan bahwa variabel yang paling dominan mempengaruhi kepatuhan perawat adalah variabel sikap dengan nilai $\operatorname{Exp}(B)$ sebesar 16.875 yang dapat diartikan bahwa Sikap memiliki 16.875 kali lebih berpeluang mempengaruhi kepatuhan perawat dalam mencuci tangan. Hal ini dapat disimpulkan bahwa variabel Sikap merupakan faktor utama dalam meningkatkan kepatuhan perawat dalam mencuci tangan. Dengan demikian, variabel tersebut menjadikan suatu bukti bahwa dengan memberikan sikap yang baik maka akan mencerminkan kepatuhan yang baik pula, sehingga dapat meningkatkan mutu pelayanan di Rumah Sakit.

\section{PENUTUP}

Dari permasalahan dan pembahasan yang dikaji pada bab-bab terdahulu, maka penulis menarik kesimpulan sebagai berikut. 
1. Ada pengaruh antara pengetahuan responden dengan kepatuhan perawat dalam mencuci tangan di RSUD Datu Beru Takengon dengan p.value 0,001.

2. Ada pengaruh antara sikap responden dengan kepatuhan perawat dalam mencuci tangan di RSUD Datu Beru Takengon dengan p.value 0,000.

3. Ada pengaruh antara fasilitas dengan kepatuhan perawat dalam mencuci tangan di RSUD Datu Beru Takengon dengan p.value 0,025.

4. Ada pengaruh antara peran Tim PPI dengan kepatuhan perawat dalam mencuci tangan di RSUD Datu Beru Takengon dengan p.value 0,011.

5. Analisis multivariat diperoleh bahwa variabel yang paling mempengaruhi kepatuhan perawat dalam mencuci tangan adalah variabel sikap dengan nilai $\operatorname{Exp}(B)$ sebesar 16.875 yang dapat diartikan bahwa sikap memiliki 16.875 kali lebih berpeluang mempengaruhi kepatuhan perawat dalam mencuci tangan.

\section{DAFTAR PUSTAKA}

Anonimous, 2009. Undang-Undang RI No. 44 Tahun 2009 tentang Rumah Sakit. Jakarta.

Bady, Agus Mawroto et all. (2007). Analisis kinerja perawat dalam pengendalian infeksi Nosokomial di IRNA I Rsup Dr. Sardjito. Diakses pada tanggal 19 desember 2016.

Darmadi, 2008. Infeksi Nosokomial : Problematika Dan Pengendaliannya. Jakarta: Penerbit Salemba Medika.

Depkes RI., 2008 Keputusan Menteri Kesehatan RI Nomor 129/MENKES/SK/II/ 2008 tentang Standar Pelayanan Minimal Rumah Sakit.

Hasnadi, Ryan Indriwan, dan Mahlil, 2014. Gambaran Pengetahuan Kepala Keluarga tentang Prilaku Hidup Bersih dan Sehat (PHBS) di Gampong Meureu Lamglumpang Kecamatan Indrapuri Kabupaten Aceh Besar Tahun 2014. http://ojs.serambimekkah.ac.id/index.php/serambi-saintia/article/view/92/90

Perdalin, 2010. Handout Pengendalian Infeksi Nasokomial. Jakarta.

Sumiarty, 2016. kepatuhan perawat mencuci tangan. http://www.academia.edu/10224014/. Diakses pada 20 desember 2016 